\title{
Rapidly generating knockout mice from H19-lgf2 engineered androgenetic haploid embryonic stem cells
}

\author{
Meili Zhang ${ }^{1,2,5}$, Yufang Liu ${ }^{1,2,5}$, Guang Liu ${ }^{1,2,5}$, Xin $\mathrm{Li}^{3,5}$, Yuyan Jia ${ }^{1,2}$, Lihong Sun ${ }^{4}$, Liu Wang ${ }^{3}$, Qi Zhou ${ }^{3}$, \\ Yue Huang ${ }^{1,2}$ \\ ${ }^{1}$ State Key Laboratory of Medical Molecular Biology, Institute of Basic Medical Sciences, Chinese Academy of Medical Sciences \\ \& Peking Union Medical College, Beijing 100005, China; ${ }^{2}$ Department of Medical Genetics, Institute of Basic Medical Sciences, \\ Chinese Academy of Medical Sciences \& Peking Union Medical College, Beijing 100005, China; ${ }^{3}$ State Key Laboratory of \\ Reproductive Biology, Institute of Zoology, Chinese Academy of Sciences, Beijing 100101, China; ${ }^{4}$ Center for Experimental \\ Animal Research, Institute of Basic Medical Sciences, Chinese Academy of Medical Sciences \& Peking Union Medical College, \\ Beijing 100005, China
}

Haploid mammalian embryonic stem cells (ESCs) hold great promise for functional genetic studies and assisted reproduction. Recently, rodent androgenetic haploid ESCs (AG-haESCs) were generated from androgenetic blastocysts and functioned like sperm to produce viable offspring via the intracytoplasmic AG-haESCs injection into oocytes. However, the efficiency of this reproduction was very low. Most pups were growth-retarded and died shortly after birth, which is not practical for producing knockout animals. Further investigation suggested a possible link between the low birthrate and aberrant expression of imprinted genes. Here, we report the high-frequency generation of healthy, fertile mice from H19-Igf2 imprinting-locus modified AG-haESCs, which maintained normal paternal imprinting and pluripotency. Moreover, it is feasible to perform further genetic manipulations in these AG-haESCs. Our study provides a reliable and efficient tool to rapidly produce gene-modified mouse models and will benefit reproductive medicine in the future.

Keywords: Haploid ES cells; AG-haESCs; imprinted gene; ICAHCI; gene-modified mice

Cell Discovery (2015) 1, 15031; doi:10.1038/celldisc.2015.31; published online 3 November 2015

\section{Introduction}

Recently, mammalian haploid embryonic stem cell (ESC) lines were successfully established in mouse, rat and monkey [1-4]. They displayed unique potential for functional genetic studies and hold great promise for assisted reproduction [5, 6]. Moreover, androgenetic haploid ESCs (AG-haESCs) were isolated from androgenetic rodent blastocysts and functioned like sperm to produce viable, fertile progeny after intracytoplasmic injection into mature oocytes [3, 7, 8], providing a new approach for rapidly producing genetically modified mice. However, the efficiency was

${ }_{5}^{5}$ These authors contributed equally to this work.

Correspondence: Yue Huang

Tel: +86 10 69156462; Fax: +8610 65284022;

E-mail: huangyue@pumc.edu.cn

Received 24 August 2015; accepted 17 September 2015 extremely low, and many of these semi-cloned (SC) pups were growth-retarded and died shortly after birth, most likely due to instable paternal imprinting in these AG-haESCs.

Genomic imprinting has an essential role in mammalian development [9-11]. Among the $~ 150$ reported murine imprinted genes, the H19-Igf2 locus was first identified and shown to be essential for normal fetal growth $[12,13]$. Furthermore, viable bi-maternal mice were produced from reconstructed eggs containing fully grown oocytes and non-growing oocytes that harbored a deletion in the H19-Igf2 locus [14]. Interestingly, abnormal H19 imprinting was observed in the prolonged cultured AG-haESCs and growth-retarded newborns mentioned above [7, 8]. We therefore asked whether genetic modification of the H19-Igf2 locus in AG-haESCs could yield fertile transgenic mice at a high frequency. 


\section{Results}

Genetic modification of the H19-Igf2 locus in AG-haESCs

The mouse $H 19$ gene produces a $2.3 \mathrm{~kb}$ long noncoding RNA exclusively expressed from the maternal allele and physically linked to the $I g f 2$ gene on chromosome 7 . They are reciprocally imprinted. The imprinting control region (ICR) within the H19-Igf2 locus is essential for transcriptional insulation of the maternal $I g f 2$ allele [15]. To disrupt $H 19$ gene expression in AG-haESCs, we used clustered regularly interspaced short palindromic repeat (CRISPR)-Cas9 enhanced homologous recombination $[16,17]$ to knock out the $13 \mathrm{~kb}$ region of $H 19$ that includes the transcription unit and the ICR (Figure 1a). We designed four single guide RNAs (sgRNAs) targeting different sites up- or downstream of the region and investigated the specificity of these sgRNAs via the Surveyor assay [18]. Cas9/sgRNA-4 and Cas9/sgRNA-7 transfection efficiently cleaved at the target loci and were used for gene targeting (Figure 1b). We co-transfected the pCCI-H19, Cas9-sgRNA-4 and Cas9-sgRNA-7 plasmids into AGH-OG-3 AG-haESCs harboring the Oct4 promoter-driven eGFP (Oct4-eGFP) transgene. The positive clones were examined by PCR (Figure 1c) and were further validated by Southern blot analysis (Figure 1d). Among the 96 picked colonies, 29 positive clones harbored the desired H19-ICR deletion $\left(H 19^{4}\right)$. We randomly chose two clones containing considerable haploid cells for further experiments. The two AG-haESC lines, referred to as $H 19^{\Delta 1}$ and $H 19^{\Delta 2}$, were established through consecutive passages and multiple rounds of fluorescence-activated cell sorting (FACS) for haploid cells (Figure 1e). Karyotyping analysis showed that these cells contained a haploid set of 20 chromosomes (Figure 1f). Comparative genomic hybridization $(\mathrm{CGH})$ analysis confirmed the genome integrity of the two haploid cell lines (Supplementary Table S1). Analyses of potential off-target regions showed that none of the eight predicted sites were mutated by CRISPR/Cas9 in the two-cell clones (Figure 1g).

\section{Characteristics of $H 19^{\perp}$ AG-haESCs}

Cultured $H 19^{\triangle}$ AG-haESCs exhibited dome-shaped colony morphology similar to diploid mouse ESCs and expressed the pluripotency genes Oct4, Sox2, Nanog and SSEAI (Figure 2a). These cells formed embryoid bodies when cultured in suspension (Figure 2b). The pluripotency was further tested by injection of the $H 19^{4} \mathrm{AG}$-haESCs into diploid ICR blastocysts derived from mice with white coats. One chimeric mouse was obtained and survived to adulthood without obvious defects (Figure 2c). These studies provided evidence for the pluripotency of $H 19^{\Delta}$ AG-haESCs.

We then analyzed whether the H19-ICR deletion affected the imprinting status of AG-haESCs. We first examined the expression of H19, Igf2, Snrpn (maternally imprinted), Grb10 (paternally imprinted) and Gtl2 (paternally imprinted) in AGH-OG-3 and the two $H 19^{\Delta}$ haploid cell lines. As expected, the expression of $H 19$ was nearly undetectable in the two $\mathrm{H}^{4} \mathrm{9}^{\mathrm{S}}$ cell lines, whereas the $\operatorname{Ig} f 2$ level was significantly upregulated (Figure 2d). Snrpn and Grb10 expression in $H 19^{4} \mathrm{AG}-$ haESCs was comparable to expression in AGH-OG-3 AG-haESCs (Figure 2d). Interestingly, the expression level of $G t / 2$ in the two $H 19^{4}$ cell lines was varied. Gtl2 was expressed at low levels in $H 19^{\Delta 1}$ AG-haESCs, whereas its expression in $H 19^{\Delta 2}$ AG-haESCs was similar to AGH-OG-3 cells (Figure 2d). This demonstrated the intraclonal heterogeneity of Gtl2 expression in AGH-OG-3 cells. To further assess the DNA methylation profile of the imprinted genes, we performed bisulfite sequencing to analyze the ICRs of the Snrpn and Gtl2 loci. H19 $9^{\Delta l}$ AG-haESCs showed normal methylation patterns similar to sperm in the ICRs of Snrpn and Gtl2, whereas late-passage (p65) AGH-OG-3 cells displayed abnormal methylation in the Gtl2 ICR. H19 $9^{42}$ AG-haESCs harbored an abnormal methylation of the Gtl2 ICR similar to AGH-OG-3 cells (Figure 2e). The normal Gtl2 ICR methylation in $H 19^{\Delta 1} \mathrm{AG}$-haESCs indicated that some late-passage AGH-OG-3 cells maintained normal imprinting of the Gtl2 ICR. The methylation status of the Snrpn and Gtl2 ICRs in $H 19^{\Delta l}$ and $H 19^{\Delta 2} \mathrm{AG}$-haESCs was consistent with the expression of Snrpn and Gtl2 in these cells. These results indicated that H19-ICR deletion in AG-haESCs had a negligible impact on the imprinting status of genes except for the H19-Igf2 locus.

$H 19^{4}$ AG-haESCs efficiently support the generation of healthy SC mice

We were interested in testing whether H19-ICR deletion in AG-haESCs increased the efficiency of producing offspring. We injected FACS-sorted G0- or G1- phase $H 19^{\perp} \mathrm{AG}$-haESCs into pre-activated oocytes via intracytoplasmic AG-haESCs injection (ICAHCI). $H 19^{4} \mathrm{AG}$-haESCs contributed to embryos, as judged by Oct4-eGFP expression in developed blastocysts (Figure 3a). We transferred 80 two-cell embryos from the $H 19^{\Delta l} \mathrm{AG}-\mathrm{haESC}$ line into two pseudopregnant ICR mice and obtained three female full-term pups. 
a
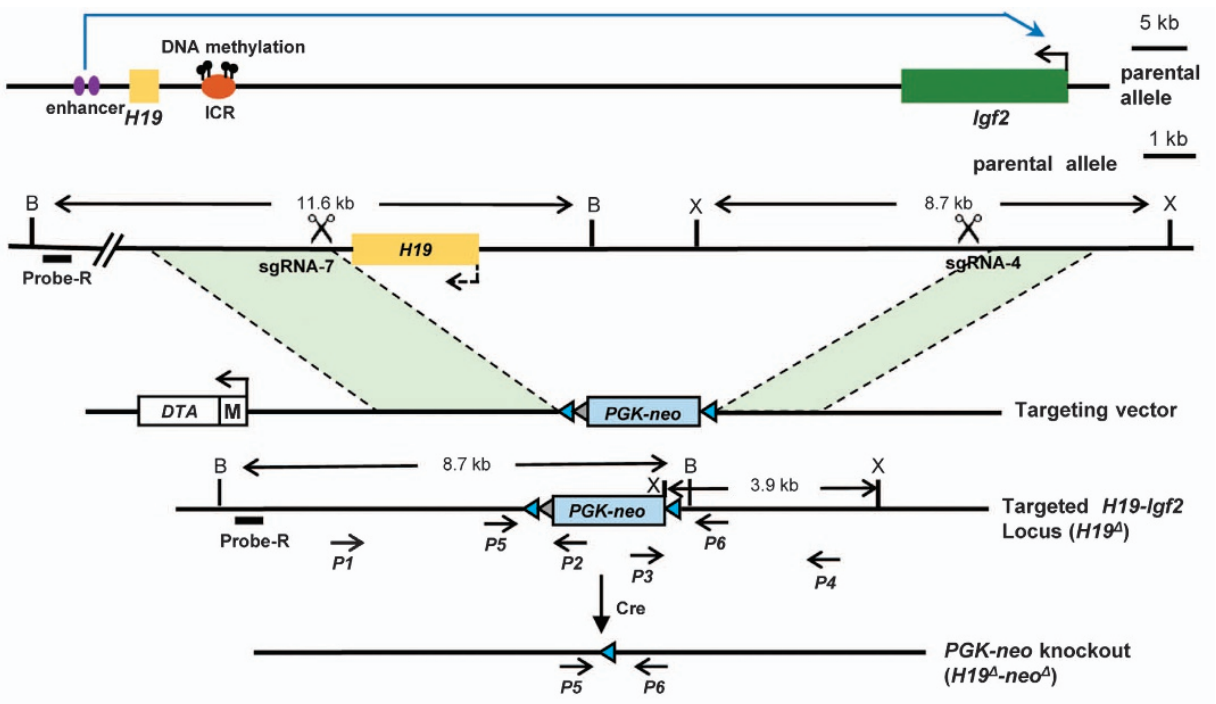

b
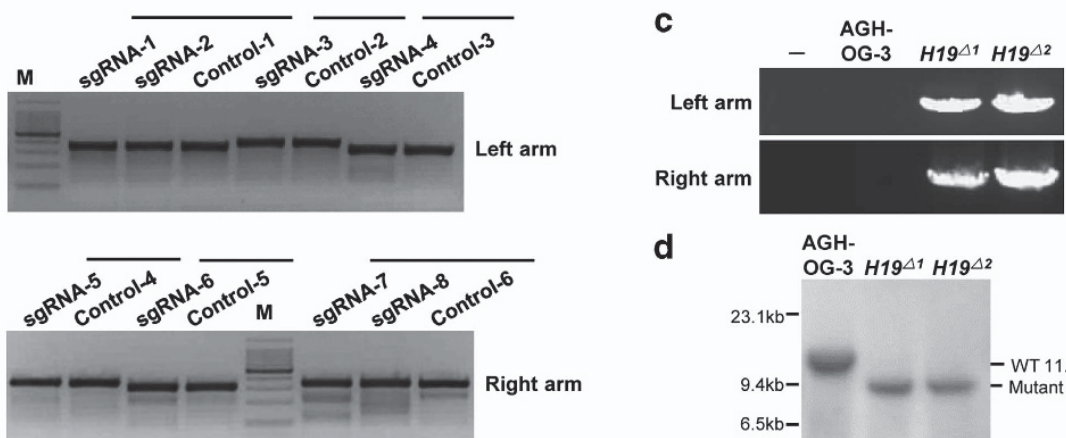

d
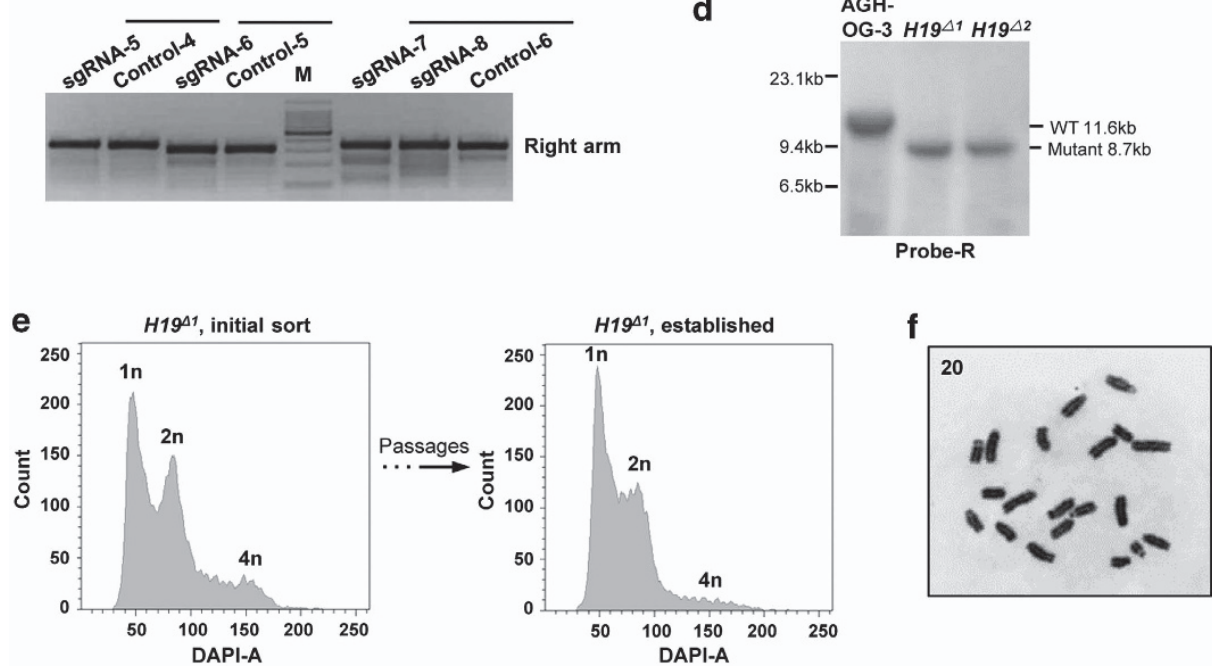

g

\begin{tabular}{|c|c|c|c|c|}
\hline \multirow{2}{*}{$\begin{array}{l}\text { Potential off-target sites } \\
\text { (sgRNA-7) }\end{array}$} & \multirow{2}{*}{ Gene } & \multirow{2}{*}{ Sequence (5'-3') } & \multicolumn{2}{|c|}{ Target } \\
\hline & & & H1941 & $H 19^{\Delta 2}$ \\
\hline Chr14:64099281-64099303 & NR_046192 & GGCCCTCTCACTTCCTGCTCTGG & No & No \\
\hline Chr14:36890307-36890329 & NM 027045 & СTCTCACTCCСATCCTGCTCTGG & No & No \\
\hline Chr7:79776576-79776598 & NM-001037927 & GGCTCTCGCAGATCCTGCTCCAG & No & No \\
\hline Chr15:84115610-84115632 & NM_029427 & GGCTATCTCACCTCCTGCTCCGG & No & No \\
\hline Chr5:96793296-96793318 & NM_013470 & GTCTCCCTCACATCCTCCTCCAG & No & No \\
\hline Chr19:44149276-44149298 & NM 181422 & GTCTCTCTCAAATCCTACTCAGG & No & No \\
\hline Chr12:110932985-110933007 & NM_001081057 & GCACCTCCCACATCCTCСTCTGG & No & No \\
\hline Chr19:10881639-10881661 & $\mathrm{NM}^{-} 134142$ & GGCCCTCACTCACCCTGCTCCGG & No & No \\
\hline
\end{tabular}

Figure 1 Genetic modification of the H19-lgf2 locus in AG-haESCs. (a) Schematic representation of CRISPR-Cas9 assisted homologous recombination to target the H19-lgf2 locus in AG-haESCs (H19^AG-haESCs). The PGK-neo cassette was deleted by Cre (H19 ${ }^{4}$-neo ${ }^{4}$ AG-haESCs). (b) Surveyor assay for Cas9-mediated cleavage up- and downstream of the $H 19$ locus in AG-haESCs. (c) Validation of gene targeting in $\mathrm{H}_{19^{4}}$ AG-haESCs by PCR. (d) Confirmation of gene targeting in $\mathrm{H}^{4} 9^{4} \mathrm{AG}-$ haESCs by Southern blot. (e) Establishment of the $H 19^{41}$ AG-haESC line after FACS enrichment for haploid cells. (f) Karyotype of $H 19^{\Delta 1}$ AG-haESCs showing normal haploidy. (g) Identification of the potential off-targets of CRISPR-Cas9 in $\mathrm{H}_{19}^{4} \mathrm{AG}-\mathrm{haESCs}$. 

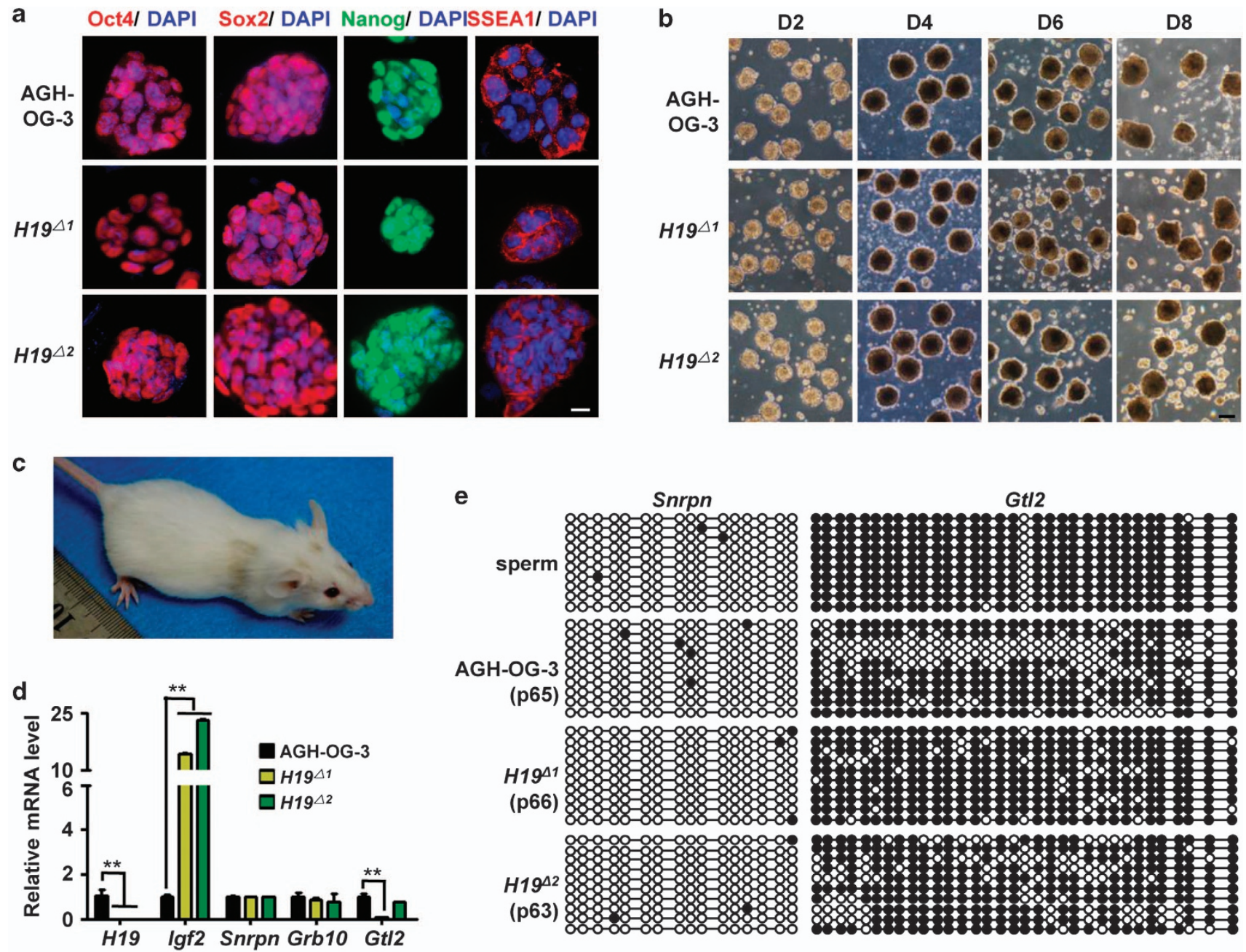

Snrpn
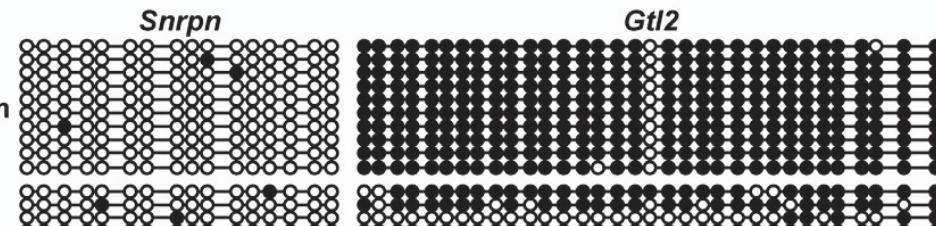

Figure 2 Characteristics of $H 19^{4}$ AG-haESCs. (a) Immunofluorescence staining of AGH-OG-3 and $H 19^{4}$ AG-haESCs. Scale bar, $20 \mu \mathrm{m}$. (b) Different days of embryoid bodies (EB) formation of AGH-OG-3 and H194AG-haESCs. Scale bar, $200 \mu \mathrm{m}$. (c) Adult chimeric mouse produced by microinjection of haploid $H 19^{41} \mathrm{AG}-$ haESC into diploid blastocysts. (d) Expression of imprinted genes measured by quantitative reverse transcription PCR (RT-qPCR). AGH-OG-3 AG-haESCs were used as control. Error bars, \pm s.d. $n=3 .{ }^{* *} P<0.01$. (e) Methylation analysis of the Snrpn and Gt/2 DMRs in H194AG-haESCs. Sperm DNA was used as control. Open circles represent unmethylated $\mathrm{CpG}$ sites, whereas filled circles represent methylated CpG sites.

All pups had normal body size and did not exhibit obvious developmental retardation after birth (Figure 3b). Two pups grew to adulthood with black (SC-Black) and agouti (SC-Agouti) fur, respectively (Figure $3 \mathrm{c}$ and d). Because $H 19^{\Delta 1}$ AG-haESCs had a C57BL/6 background, the black or agouti coat colors of SC mice depended on the oocytes used for ICAHCI, which were derived from CD-1 or B6D2F1 (C57BL/ $6 \times \mathrm{DBA} / 2)$ mice, respectively. The $\mathrm{SC}$ mice delivered healthy progeny with litter sizes of $8-10$ when mated with C57BL/6 males (Figure 3e and g). We obtained three SC-Black litters and two SC-Agouti litters. Approximately half of these carried the H19-ICR deletion, consistent with the expected Mendelian ratio (Figure $3 \mathrm{f}$ and $\mathrm{h}$ ). The rate of SC mice born was $\sim 4 \%$ of $H 19^{\Delta l}$ AG-haESCs ICAHCI (Table 1) compared with the $\sim 2.2 \%$ efficiency of generating SC mice from early passage AGH-OG-3 (passage 17) AG-haESCs ICAHCI and $\%$ from late-passage AGH-OG-3 cells (passage 22) [7]. Many of the AGH-OG-3 AG-haESC derived pups were growth-retarded and died within $1 \mathrm{~h}$ of birth [7]. However, no growth-retarded pups were produced from $H 19^{\Delta l} \mathrm{AG}$-haESCs ICAHCI, even though the cells were from a very late passage (more than passage 56). The growth retardation of SC mice might be due to the loss of methylation in the H19 ICR 
a

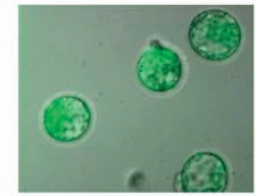

e

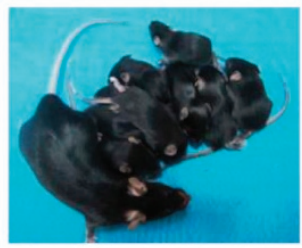

b

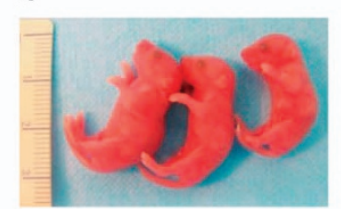

C

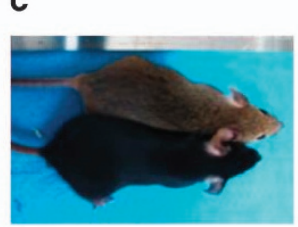

d

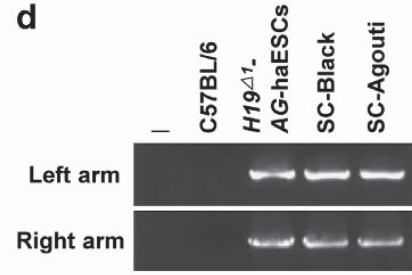

$\mathbf{f}$

f

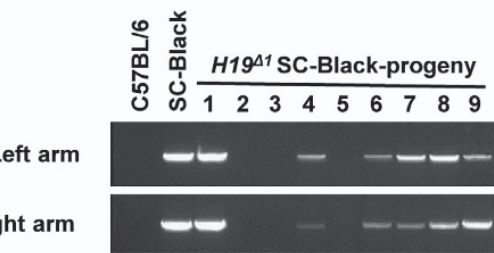

g
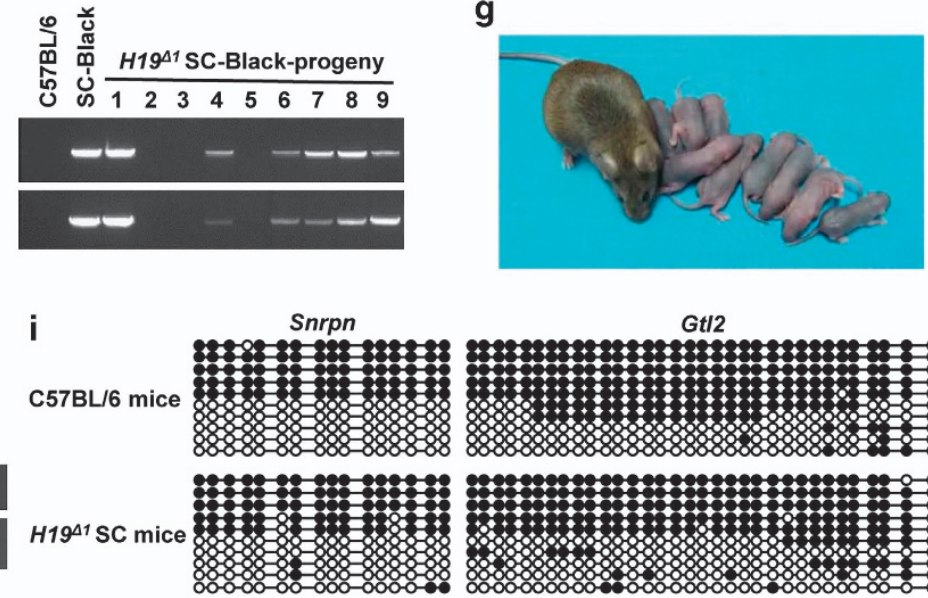

h

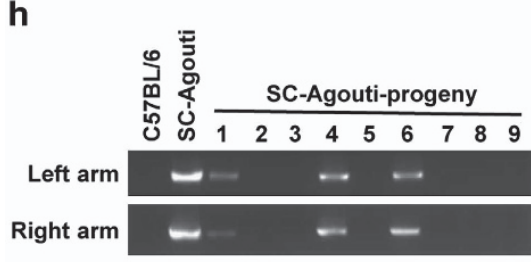

Gt/2

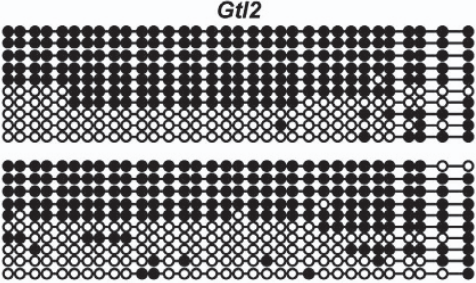

Figure 3 Generation of ICAHCl offspring by $H 19^{\Delta 1} \mathrm{AG}-$ haESCs. (a) Blastocysts generated by injection of $H 19^{\Delta 1} \mathrm{AG}-\mathrm{haESC}$ into oocytes. The $H 19^{\Delta 1} \mathrm{AG}-\mathrm{haESC}$ carried the Oct4-eGFP transgene. (b) Three SC pups from ICAHCI using $H 19^{41} \mathrm{AG}-\mathrm{haESCs}$. (c) Adult SC mice derived from ICAHCl using $H 19^{41}$ AG-haESCs. (d) PCR analysis of $H 19$ deletion in SC mice. (e) Adult $H 19^{41}$ SCBlack mouse and its progeny. (f) PCR analysis of $H 19$ deletion in the progeny of $H 19^{4}$ SC-Black mice. The primer pairs P1-P2 and P3-P4 were used. (g) Adult $H_{1} 19^{4}$ SC-Agouti mouse and its progeny. (h) PCR analysis of the $H 19$ deletion in the progeny of SC-Agouti mice. (i) Methylation analysis of imprinting in $\mathrm{H}_{1} 9^{41} \mathrm{SC}$ pups. C57BL/6 mice DNA was used as control. Open circles represent unmethylated $\mathrm{CpG}$ sites, whereas filled circles represent methylated CpG sites.

and the consequent lower expression of $\operatorname{Ig} f 2$. In $\mathrm{SC}$ mice generated by $H 19^{4 l}$ AG-haESCs ICAHCI, H19$I C R$ was deleted, leading to the normal expression of Igf2. The methylation status of two other imprinted genes, Snrpn and Gtl2, was normal in SC mice (Figure 3i). These results demonstrated that $\mathrm{H}_{19^{4} \mathrm{AG}-}$ haESCs could function like sperm to produce normal mice and transmit their genetic material to progeny. Thus, modification of the H19-Igf2 locus was sufficient to generate healthy and fertile SC mice at a high efficiency.

Generation of genetically modified mice using $H 19^{4}$ AG-haESCs

To further analyze the feasibility of producing genetically modified mouse models from $H 19^{4}$ AG-haESCs, we deleted a loxP flanked $P G K$-neo cassette by transient expression of Cre in the $H 19^{\Delta l}$ AG-haESC line (Figure 1a). Among the 96 picked clones, the PGK-neo cassette was correctly deleted in most clones, as analyzed by PCR
(Figure 4a). The remaining loxP site in the H19-Igf2 locus was further confirmed by DNA sequencing (Figure 4b). We then randomly chose 24 correctly deleted clones $\left(H 19^{\Delta l}-n e o^{\Delta}\right)$ and performed FACS to determine the haploid subpopulation in these clones. The haploid ESC lines were established through consecutive passages, followed by two rounds of FACS for haploid cells (Figure 4c). The $H 19^{\Delta l}{ }_{-n e o^{4}}$ AG-haESCs had normal haploid karyotypes (Figure $4 \mathrm{~d}$ and e), expressed pluripotency markers (Figure 4f), and imprinted genes comparable to $H 19^{4} \mathrm{AG}$-haESCs (Figure 4g). After injecting the sorted G0- or G1- phase $H 19^{\Delta l}$-neo ${ }^{\Delta l} \mathrm{AG}$-haESCs into the pre-activated oocytes, we successfully obtained 50 two-cell stage embryos and transplanted them into pseudopregnant females. One full-term live pup derived from the $H 19^{\Delta l}-n e o^{\Delta l}$ AG-haESC line was obtained (Table 1). Genotype analysis confirmed $P G K$-neo cassette deletion in the SC animal (Figure 4h). Our results demonstrated that $H 19^{4} \mathrm{AG}$-haESCs can be used to rapidly generate genemodified mice. 
Table 1 Developmental efficiencies of ICAHCI embryos

\begin{tabular}{|c|c|c|c|c|c|c|}
\hline $\begin{array}{l}\text { Donor } \\
\text { AG-haESCs }\end{array}$ & $\begin{array}{l}\text { Passage } \\
\text { number }\end{array}$ & $\begin{array}{l}\text { Embryo } \\
\text { stage }\end{array}$ & $\begin{array}{l}\text { Number of } \\
\text { transferred } \\
\text { embryos }\end{array}$ & $\begin{array}{c}\text { No. of normal pups } \\
\text { (\% of transferred } \\
\text { embryos) }\end{array}$ & $\begin{array}{c}\text { No. of pups surviving to } \\
\text { adulthood (\% of transferred } \\
\text { embryos) }\end{array}$ & $\begin{array}{c}\text { No. of Growth-retarded } \\
\text { pups (\% of transferred } \\
\text { embryos) }\end{array}$ \\
\hline$\overline{\mathrm{OG}-3^{\mathrm{a}}}$ & p22 & $\begin{array}{l}\text { Two-cell } \\
\text { embryo }\end{array}$ & 102 & 0 & 0 & $3(2.9)$ \\
\hline$H 19^{41}$ & $>\mathrm{p} 56$ & $\begin{array}{l}\text { Two-cell } \\
\text { embryo }\end{array}$ & 80 & $3(3.8)$ & $2(2.5)$ & 0 \\
\hline$H 19^{\Delta 1}-n e o^{\Delta 1}$ & - & $\begin{array}{l}\text { Two-cell } \\
\text { embryo }\end{array}$ & 50 & $1(2)$ & ND & 0 \\
\hline $\begin{array}{l}\text { Round } \\
\text { spermatids }\end{array}$ & - & $\begin{array}{l}\text { Two-cell } \\
\text { embryo }\end{array}$ & 61 & $5(8.2)$ & $5(8.2)$ & 0 \\
\hline
\end{tabular}

Abbreviations: AG-haESCs, androgenetic haploid embryonic stem cells; ICAHCI, intracytoplasmic AG-haESCs injection; ND, not determined. ${ }^{\text {Th The data }}$ were from Yang et al. ${ }^{7}$

\section{Discussion}

Although we do not know why the paternally imprinted gene $\mathrm{H} 19$ easily lost methylation in AG-haESCs, successful restoration of Igf2 expression by $H 19-I C R$ deletion faithfully improved the efficiency to generate viable SC mice. Other imprinted genes, such as Grb10, Dlk1 and Gtl2, also affect embryonic growth [11]. Moreover, Dlk1-Dio3 ICR deletion significantly increased the efficiency of generating parthenogenetic mice [14, 19]. It is tempting to investigate whether additional modification of these imprinted genes in AG-haESCs would increase the efficiency of producing SC mice, although the expression level and methylation status of these genes in AG-haESCs were comparable to those in sperm [7, 8]. During the submission of this work, an independent study [20] reported the highly efficient generation of healthy and fertile SC pups from AG-haESCs carrying deletions in the H19-DMR alone or in addition with $G t l 2$-DMR, confirming our findings. Gtl2-DMR deletion ensured the full silencing of the paternally imprinted gene Gtl2 in AG-haESCs, consistent with the normal imprinting status of $G t l 2$ in $H 19^{\Delta l}$ AG-haESCs.

Modification of the H19-Igf2 locus in AG-haESCs faithfully improved the efficiency of generating healthy SC mice via the ICAHCI technology. Our work provides another approach for quickly generating gene-modified mice in addition to the VelociMouse [21] and CRISPR-Cas9 [22] technologies. The $H 19^{4}$ AG-haESCs have 'sperm-like' activity and can replace sperm in reproduction to overcome their limitations. Sperm are not able to propagate and are thus difficult to genetically modify in vitro. In addition, many established methods and resources for genetic studies of diploid ES cells are immediately applicable to $H 19^{4} \mathrm{AG}$-haESCs. This work provides inspiration for possible human AG-haESC research and may benefit male infertility in the future, similar to the contribution of spermatogonial stem cells [23].

\section{Materials and methods}

\section{Mice}

All mouse experimental protocols were approved by the Institutional Animal Care and Use Committee at Peking Union Medical College \& Chinese Academy of Medical Sciences. And all animal care and experimental methods were carried out in accordance with the institutional ethical guidelines for animal experiments. Male mice of $\mathrm{C} 57 \mathrm{BL} / 6$ were used for sperm collection. B6D2F1 (C57BL/6 $\times \mathrm{DBA} / 2)$ and $\mathrm{CD}-1$ female mice were used to provide oocytes for micromanipulation. Female mice of ICR were used to provide blastocysts for microinjection and were also used as pseudopregnant mice. C57BL/6 mice were used for animal mating.

\section{AG-haESCs}

Androgenetic haploid ES cell line AGH-OG-3 was obtained from Dr Jinsong Li's lab in Shanghai (China). The cells were cultured in ESC medium supplemented with $15 \%$ fetal bovine serum, $1000 \mathrm{U} \mathrm{ml}^{-1}$ leukemia inhibitory factor, $3 \mu \mathrm{M}$ CHIR99021 and $1 \mu \mathrm{m}$ PD0325901.

\section{DNA content analysis}

The dissociated cells were incubated with $10 \mu \mathrm{g} \mathrm{ml}^{-1}$ Hoechst 33342 at $37^{\circ} \mathrm{C}$ for $30 \mathrm{~min}$. Then the haploid $1 \mathrm{n}$ peak was purified by flow-cytometry (BD FACSAria III, San Jose, CA, USA). Flow-cytometric data were analyzed using the BD FACSDiva software.

\section{Vector construction}

For pCCI-H19 construction, the left and right homologous arms were amplified from bacterial artificial chromosome (RP23-209022). Eag I and Pac I restriction sites were 
a

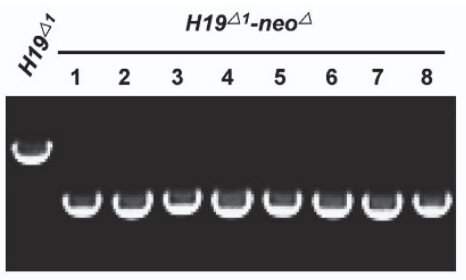

b

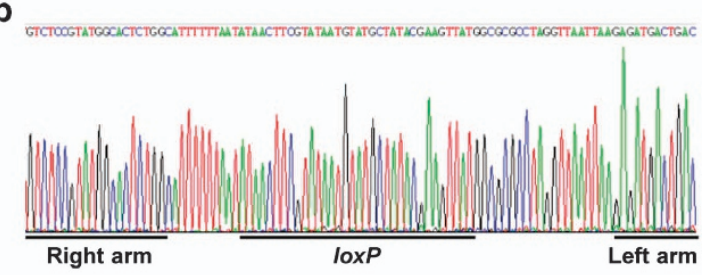

C
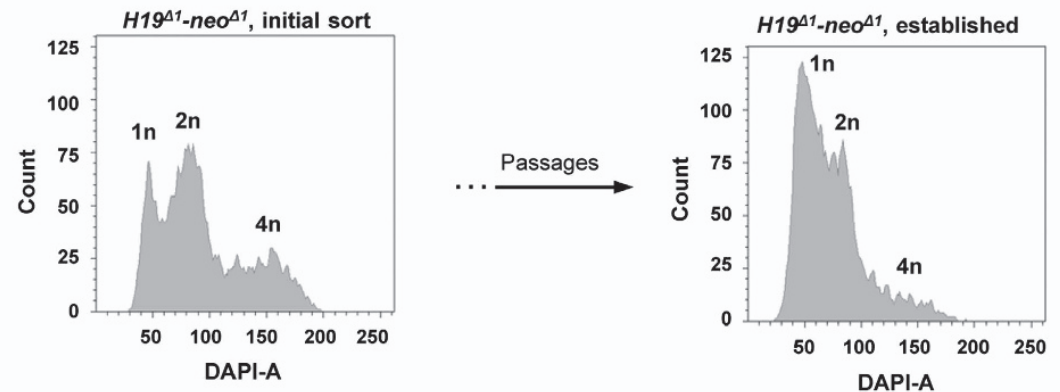

d
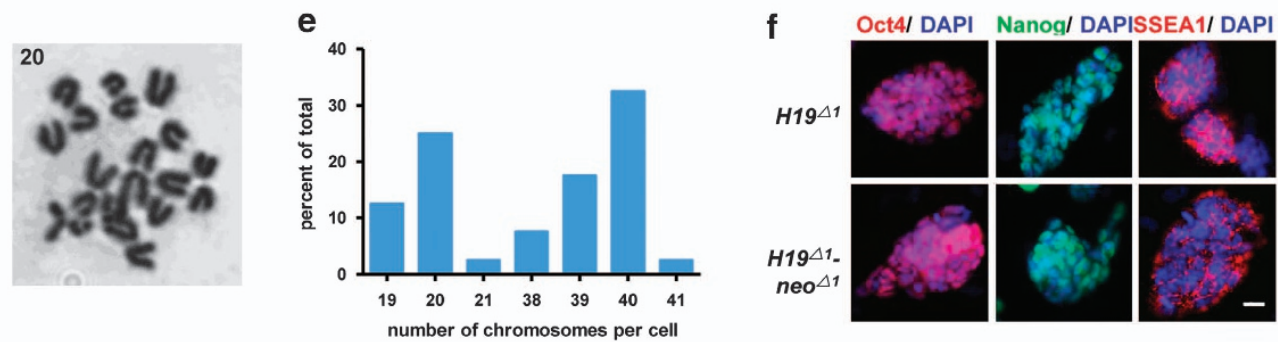

g

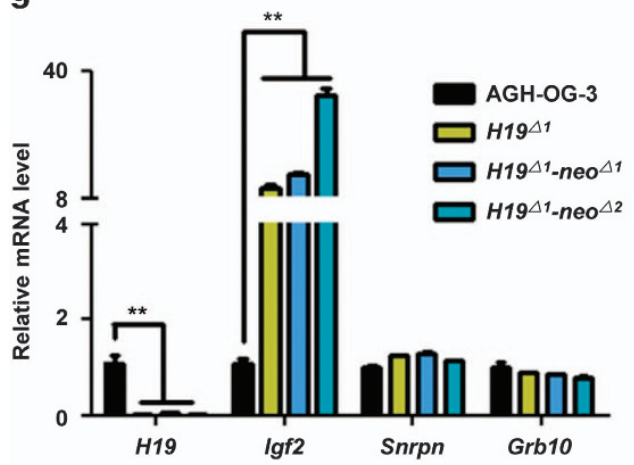

h

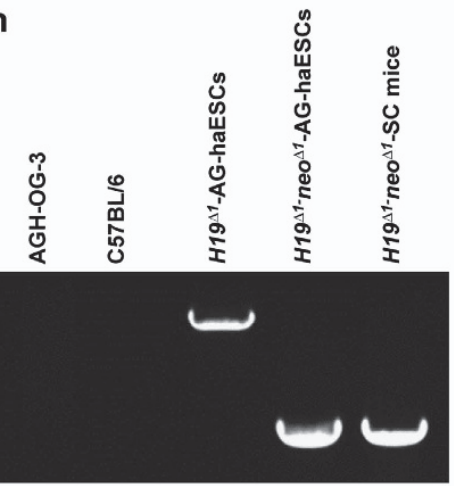

Figure 4 Generation of ICAHCl offspring by $H 19^{\Delta 1}$-neo ${ }^{\Delta} \mathrm{AG}$-haESCs. (a) Subclones of $P$ GK-neo knockouts in $H 19^{\Delta 1} \mathrm{AG}-\mathrm{haESCs}$ by PCR. The primer pairs P5-P6 were used. (b) DNA sequence of PCR products amplified from the $H 19$ gene of $H 19^{\Delta 1}$-neo ${ }^{\Delta}$ AG-haESCs. (c) Establishment of the $H 19^{\Delta 1}$-neo ${ }^{\Delta 1}$ AG-haESC line after FACS enrichment for haploid cells. (d) Chromosome counting in $H 19^{\Delta 1}-n e 0^{\Delta 1} \mathrm{AG}-$ haESCs showing normal haploidy. (e) The distribution of absolute chromosome numbers of $\mathrm{H}_{19^{41}}$-neo ${ }^{\Delta 1} \mathrm{AG}$-haESCs under cell culture conditions. (f) Immunofluorescence staining of $\mathrm{H} 19^{4}$ and $H 19^{\Delta 1}-n e o^{\Delta 1} A G-h a E S C s$. Scale bar, $20 \mu \mathrm{m}$. (g) Expression of imprinted genes measured by quantitative reverse transcription PCR (RT-qPCR). AGH-OG-3 AG-haESCs were used as control. Error bars, \pm s.d. $n=3$. ${ }^{* *} P<0.01$. (h) PCR analysis of $P G K-n e o$ knockout in $H 19^{\Delta 1}$-neo ${ }^{\Delta 1}$ SC mice.

added to the amplified left homologous arm, and Sma I and Xho I sites were added to the right arm. Eag I and $P a c$ I digested left arm was cloned into pCCI18 backbone (digested with Not I and Pac I). The products were then digested with Xho I and ligated with Sma I and Xho I digested right arm.

\section{Construction of CRISPR plasmids}

The pX330 plasmid was bought from Addgene, Cambridge, MA, USA. The sgRNA-1, $-2, \quad-3, \quad-4, \quad-5, \quad-6, \quad-7$ and -8 oligos were synthesized, annealed and ligated to the pX330 plasmid that was digested with Bbs I (New England Biolabs, Ipswitch, MA, USA). The sequences 
of designed sgRNAs were listed in Supplementary Table S2.

Surveyor assay

The AG-haESCs were transfected with CRISPR-sgRNA plus pPB-puro plasmids and selected by puromycin for $36 \mathrm{~h}$. Genomic DNA from wild-type and transfected AG-haESCs was extracted. PCR products were denatured, annealed and treated with T7EN1 (New England Biolabs). The primers used for PCR were listed in Supplementary Table S2.

The fragmentation of sgRNAs was as follows:

\begin{tabular}{lcc} 
sgRNA & Primers & Fragment size (bp) \\
\hline sgRNA-1 & S3+S4 & $100+230$ \\
sgRNA-2 & S3+S4 & $120+220$ \\
sgRNA-3 & S5+S6 & $130+240$ \\
sgRNA-4 & S1+S2 & $130+180$ \\
sgRNA-5 & S9+S10 & $220+130$ \\
sgRNA-6 & S7+S8 & $100+200$ \\
sgRNA-7 & S11+S12 & $120+220$ \\
sgRNA-8 & S11+S12 & $140+200$ \\
\hline
\end{tabular}

\section{Gene targeting in AGH-OG-3 AG-haESCS}

The pCCI-H19, Cas9-sgRNA-4 and Cas9-sgRNA-7 plasmids were co-transfected into AGH-OG-3 AG-haESCs. The cells were selected by G418 $(150 \mu \mathrm{g} / \mathrm{ml})$ for 7 days. Colonies were picked and analyzed by PCR and flow cytometer sorting. The CAGGS-Cre plasmid was electroporated into $H 19^{\Delta I}$ AG-haESCs to delete the loxP flanked $P G K$-neo cassette.

\section{Southern blotting}

Wild-type and $H 19^{\Delta} \mathrm{AG}-\mathrm{haESC}$ genomic DNA was digested using $B g / \mathrm{II}$ restriction enzyme. The digested DNA was subsequently separated on a $1 \%$ agarose gel for $5 \mathrm{~h}$, and then transferred to a nylon membrane and hybridized with $\alpha-{ }^{32} \mathrm{P}$ random primer-labeled probes.

\section{Prediction of potential off-targets}

The potential off-target regions were predicted using the online tool, http://crispr.mit.edu/. The regions with score $>0.5$ and mismatch $\leqslant 4$ were considered as the potential off-target sites. They were amplified using High-Fidelity DNA Polymerase (New England Biolabs) and sequenced.

\section{Intracytoplasmic injection}

ICAHCI was described as previously [8]. In brief, mature oocytes were collected from the oviduct of super-ovulated female $\mathrm{B} 6 \mathrm{D} 2 \mathrm{~F} 1$ and $\mathrm{CD}-1$ mice and were pre-activated by $10 \mathrm{~mm} \mathrm{SrCl}_{2}$ in calcium-free $\mathrm{CZB}$ medium for $30 \mathrm{~min}$ before microinjection. G0- or G1-phase purified AG-haESCs were collected and injected into oocytes separately. When the constructed embryos developed to the 2-cell stage in KSOM-AA medium (Sigma, St Louis, MO, USA), they were transferred to the oviduct of pseudopregnant ICR mice at 0.5 d.p.c.

\section{Comparative genomic hybridization analysis}

The genomic DNA of wild-type and $H 19^{\Delta}$ AG-haESCs was extracted using the Wizard Genomic DNA Purification Kit (Promega, Madison, WI, USA) and sent to the CapitalBio Corporation (Changping District, Beijing, China) for $\mathrm{CGH}$ analysis. The SurePrint G3 Mouse CGH $4 \times 180 \mathrm{~K}$ microarrays (Agilent, Santa Clara, CA, USA) were used.

\section{Karyotype analysis}

Exponentially growing ES cells were incubated with $0.2 \mu \mathrm{g} \mathrm{ml}^{-1}$ colcemid (Sigma) for $2-3 \mathrm{~h}$ at $37^{\circ} \mathrm{C}$. After trypsinization, the collected cells were incubated in $0.075 \mathrm{M} \mathrm{KCl}$ hypotonic solution for $15 \mathrm{~min}$ at $37^{\circ} \mathrm{C}$. Hypotonic solution-treated ES cells were fixed in fresh ice cold 3:1 methanol/acetic acid at room temperature and dropped onto the precleaned slides. The chromosome spreads were stained with Giemsa solution $(10 \% \mathrm{v} / \mathrm{v}$ Giemsa to $7.0 \mathrm{pH}$ phosphate buffer) for $5 \mathrm{~min}$ and washed in $\mathrm{ddH}_{2} \mathrm{O}$. More than 30 metaphase spreads were analyzed.

\section{Immunostaining}

ES cells on coverslips were fixed in 4\% paraformaldehyde/ phosphate buffer saline (PBS) for $15 \mathrm{~min}$ at room temperature. The fixed cells were then permeabilized with $0.5 \%$ Triton $\mathrm{X}-100$ for $10 \mathrm{~min}$ and were blocked in 3\% bovine serum albumin for $1 \mathrm{~h}$ at room temperature. The cells were incubated overnight at $4{ }^{\circ} \mathrm{C}$ with primary antibodies, anti-oct3/4 (sc-5279; Santa Cruz, Dallas, TX, USA), anti-sox2 (sc-17320; Santa Cruz), anti-nanog (AB5731; Millipore, Billerica, MA, USA), and anti-SSEA1 (sc-21702; Santa Cruz). The cells were treated with the secondary antibodies for $1 \mathrm{~h}$ at room temperature. The nuclei were dyed with 4',6-diamidino-2-phenylindole (DAPI). Images were acquired by the fluorescent microscope (Zeiss, Oberkochen, Germany).

\section{Quantitative reverse transcription $P C R$}

Total RNA was extracted from AG-haESCs using Trizol reagent (Invitrogen, Waltham, MA, USA). $1.0 \mu \mathrm{g}$ of total RNA was reverse transcribed using the PrimeScript II 1st strand cDNA synthesis kit (TaKaRa, Dalian, China). The real-time PCR reaction was performed using SYBR Premix Ex Taq II (TaKaRa) and run on Roche 480 Light Cycler. The amount of GAPDH expression was used to normalize all values.

\section{Bisulphite sequencing}

Genomic DNA of ESCs, sperm and mouse tail was treated with the EpiTect Bisulphite (Qiagen, Hilden, Germany) for bisulphite conversion according to the manufacturer's instructions. Differentially methylated regions (DMRs) of Snrpn and Gtl2 were amplified. The PCR products were cloned into $\mathrm{pMD18-T}$ vectors (TakaRa) and sequenced for unmethylated $\mathrm{C}$ to $\mathrm{T}$ conversion. Bisulphite primers are presented in Supplementary Table S2.

\section{Embryoid-body formation}

Embryoid bodies were formed from wild-type and $H 19^{4}$ AG-haESCs. Cultured ES cells were dissociated with trypsin and sedimentated for $30 \mathrm{~min}$ at $37^{\circ} \mathrm{C} .1 .5 \times 10^{6}$ cells were transferred to low attachment 90 -mm-diameter bacteriological grade Petri dishes in differentiating medium containing highglucose Dulbecco's modified Eagle's medium (Gibco, Waltham, MA, USA), $15 \%$ fetal bovine serum, 2 mм GlutaMax, $1 \%$ non-essential amino acids, and $100 \mu \mathrm{m} \beta$-mercaptoethanol. 
embryoid bodies were replaced with fresh differentiation medium every other day.

\section{Statistical analysis}

The Student's $t$-test was used to analyze significant differences. $P<0.05$ was considered significant. The data analyses were performed using Prism GraphPad software.

\section{Accession codes}

$\mathrm{CGH}$ data are deposited at the Gene Expression Omnibus under accession number GSE67563.

\section{Conflict of Interest}

The authors declare competing financial interests.

\section{Acknowledgements}

We thank X Wang and L Cheng for technical assistance; Dr Jingsong Li (Chinese Academy of Sciences) for providing AGH-OG-3 haploid ES cell line; Dr Chunsheng Han (Chinese Academy of Sciences) for mouse sperm DNA samples. This work was supported by grants from the National Key Basic Research Program of China (2011CB965203, 2013CB967002 to $\mathrm{YH})$ and the National Natural Science Foundation of China (91231111 to $\mathrm{YH}$ ).

\section{References}

1 Leeb M, Wutz A. Derivation of haploid embryonic stem cells from mouse embryos. Nature 2011; 479: 131-134.

2 Elling U, Taubenschmid J, Wirnsberger G et al. Forward and reverse genetics through derivation of haploid mouse embryonic stem cells. Cell Stem Cell 2011; 9: 563-574.

3 Li W, Li X, Li T et al. Genetic modification and screening in rat using haploid embryonic stem cells. Cell Stem Cell 2014; 14: 404-414.

4 Yang H, Liu Z, Ma Y et al. Generation of haploid embryonic stem cells from Macaca fascicularis monkey parthenotes. Cell Res 2013; 23: 1187-1200.

5 Wutz A. Haploid mouse embryonic stem cells: rapid genetic screening and germline transmission. Annu Rev Cell Dev Biol 2014; 30: 705-722.

6 Elling U, Penninger JM. Genome wide functional genetics in haploid cells. FEBS Lett 2014; 588: 2415-2421.

7 Yang H, Shi L, Wang BA et al. Generation of genetically modified mice by oocyte injection of androgenetic haploid embryonic stem cells. Cell 2012; 149: 605-617.

8 Li W, Shuai L, Wan $\mathrm{H}$ et al. Androgenetic haploid embryonic stem cells produce live transgenic mice. Nature 2012; 490: 407-411.

9 Fedoriw A, Mugford J, Magnuson T. Genomic imprinting and epigenetic control of development. Cold Spring Harb Perspect Biol 2012; 4: a008136.

10 Barton SC, Surani MA, Norris ML. Role of paternal and maternal genomes in mouse development. Nature 1984; 311: $374-376$.
11 Plasschaert RN, Bartolomei MS. Genomic imprinting in development, growth, behavior and stem cells. Development 2014; 141: 1805-1813.

12 xBartolomei MS, Zemel S, Tilghman SM. Parental imprinting of the mouse H19 gene. Nature 1991; 351: 153-155.

13 DeChiara TM, Robertson EJ, Efstratiadis A. Parental imprinting of the mouse insulin-like growth factor II gene. Cell 1991; 64: 849-859.

14 Kono T, Obata Y, Wu Q et al. Birth of parthenogenetic mice that can develop to adulthood. Nature 2004; 428: 860-864.

15 Kaffer CR, Grinberg A, Pfeifer K. Regulatory mechanisms at the mouse Igf2/H19 locus. Mol Cell Biol 2001; 21: 8189-8196.

16 Cong L, Ran FA, Cox D et al. Multiplex genome engineering using CRISPR/Cas systems. Science 2013; 339: 819-823.

17 Mali P, Yang L, Esvelt KM et al. RNA-guided human genome engineering via Cas9. Science 2013; 339: 823-826.

18 Guschin DY, Waite AJ, Katibah GE et al. A rapid and general assay for monitoring endogenous gene modification. Methods Mol Biol 2010; 649: 247-256.

19 Kawahara M, Wu Q, Takahashi $\mathrm{N}$ et al. Highfrequency generation of viable mice from engineered bi-maternal embryos. Nat Biotechnol 2007; 25: 1045-1050.

20 Zhong C, Yin Q, Xie Z et al. CRISPR-Cas9-Mediated Genetic Screening in Mice with Haploid Embryonic Stem Cells Carrying a Guide RNA Library. Cell Stem Cell 2015; 17: 221-232.

21 Dechiara TM, Poueymirou WT, Auerbach W et al. VelociMouse: fully ES cell-derived F0-generation mice obtained from the injection of ES cells into eight-cell-stage embryos. Methods Mol Biol 2009; 530: 311-324.

22 Wang H, Yang H, Shivalila CS et al. One-step generation of mice carrying mutations in multiple genes by CRISPR/Cas-mediated genome engineering. Cell 2013; 153: $910-918$.

23 Kubota $\mathrm{H}$, Brinster RL. Technology insight: In vitro culture of spermatogonial stem cells and their potential therapeutic uses. Nat Clin Pract Endocrinol Metab 2006; 2: 99-108.

(Supplementary information is linked to the online version of the paper on the Cell Discovery website.)

This work is licensed under a Creative Commons Attribution 4.0 International License. The images or other third party material in this article are included in the article's Creative Commons license, unless indicated otherwise in the credit line; if the material is not included under the Creative Commons license, users will need to obtain permission from the license holder to reproduce the material. To view a copy of this license, visit http://creativecommons.org/licenses/by/4.0/ 